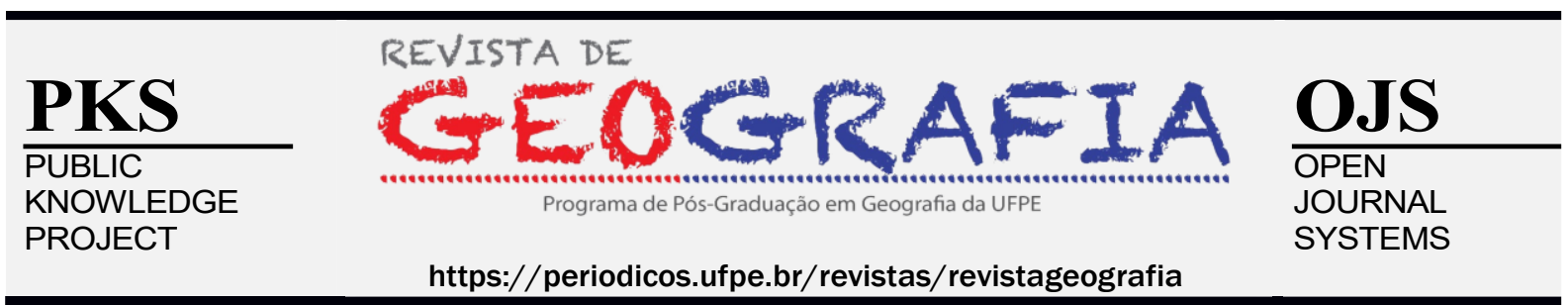

\title{
INVENTARIAÇÃO DE GEOSSÍTIOS/SÍTIOS DA GEODIVERSIDADE COSTEIROS NO SETOR SUDESTE DA ILHA DO MARANHÃO, MA-BRASIL
}

\author{
Thiara Oliveira Rabelo ${ }^{1}$ Zuleide Maria Carvalho Lima² ${ }^{2}$ arcos Antônio Leite do Nascimento ${ }^{3}$
}

\begin{abstract}
${ }^{1}$ Doutoranda do Programa de Pós-Graduação em Geografia da Universidade Federal do Rio Grande do Norte, Natal/RN.Email:thiarageo@hotmail.com.Orcid: https://orcid.org/0000-0002-6786-7376

${ }^{2}$ Dra. em Geodinâmica e Geofísica, Professora do Departamento de Geografia da Universidade Federal do Rio Grande do Norte, Natal/RN. Email: zmclima@hotmail.com.Orcid: https://orcid.org/0000-0002-6971-9801

${ }^{3}$ Dr. Em Geodinâmica e Geofísica, Professor do Departamento de Geologia da Universidade Federal do Rio Grande do Norte, Natal/RN. Email: marcos@geologia.ufrn.br.Orcid: https://orcid.org/0000-0002-8158-7186
\end{abstract}

Artigo recebido em 24/08/2020 e aceito em 11/03/2021

\begin{abstract}
RESUMO
A disseminação do conceito de geodiversidade nas últimas quatro décadas através das geociências enfatiza aa importância dos elementos abióticos para o homem e para a natureza como um todo. Autores percussores da temática como Sharples (2000), Gray (2004) e Brilha (2005) já mencionam em seus trabalhos a importância científica, cultural, turística, econômica, etc., de áreas potenciais da geodiversidade para ciência e para a sociedade. Este trabalho teve como foco inventariar 8 potenciais geossítios localizados no setor sudeste da Ilha do Maranhão, no Estado do Maranhão-Brasil. A partir dos resultados obtidos pela inventariação dos potenciais geossítios é possível observamos pelo menos três fatores que representam dinâmica de feições e processos na área, o que justifica a relevância destes locais sob ótica científica como como a presença de morros testemunhos, camadas litológicas perpendiculares a linha de costa e extensos terraços de abrasão. As áreas inventariadas também apresentam valores de relevância turístico e didático, e estas informações podem servir de base para futuros estudos sobre a geodiversidade da área assim como para ações e estratégias de gestão costeira neste setor.
\end{abstract}

Palavras-chave: Geodiversidade; Inventário; Ambiente costeiro.

\section{INVENTORY OF GEOSITIES / COASTAL GEODIVERSITY SITES IN THE SOUTHEAST SECTOR OF MARANHÃO ISLAND, MA-BRAZIL}

\begin{abstract}
The spread of the concept of geodiversity in recent decades through geosciences emphasizes the importance of abiotic elements for man and for nature as a whole. Leading authors of the theme like Sharples (2000), Gray (2004) and Brilha (2005) already mention in their work the scientific, cultural, tourist, economic importance, etc., of potential areas of geodiversity for science and for society. This work was focused on inventorying 8 potential geosites located in the southeastern sector of Ilha do Maranhão, in the State of Maranhão-Brazil. From the results obtained by the inventory of potential geosites it is possible to observe at least three factors that represent the dynamics of features and
\end{abstract}


processes in the area, which justifies the relevance of these sites under scientific optics, such as the presence of hillocks, lithological layers perpendicular to the line coastlines and extensive abrasion terraces. The inventoried areas also present values of touristic and didactic relevance, and this information can serve as a basis for future studies on the area's geodiversity as well as for coastal management actions and strategies in this sector.

Keywords Geodiversity; Inventory; Coastal environment;

\section{INTRODUÇÃO}

Com a ampla disseminação do conceito de geodiversidade nas últimas décadas é possível enfatizar através das geociências a importância dos elementos abióticos para o homem e para a natureza como um todo. Dentre vários autores que trazem em suas pesquisas o conceito de geodiversidade, destacamos aqui Canãdas e Flanõ (2007) que definem geodiversidade como a variabilidade da natureza abiótica, os processos físicos da superfície terrestre, os processos naturais e antrópicos que compreendem a diversidade de partículas, elementos e lugares.

Levando em consideração essa grande diversidade é necessário identificarmos áreas prioritárias da geodiversidade. Nesse contexto, Brilha (2016) destaca que as ocorrências que apresentam importância do ponto de vista científico são chamadas de geossítios e aquelas que não apresentam valor científico, porém apresentam valor estético, educativo, turístico, econômico, e etc., são chamados sítios da geodiversidade.

Pensando no uso sustentável dessas áreas prioritárias denominadas como geossítios ou sítios da geodiversidade destacamos a importância da inventariação para compreendermos sua formação, seus processos, potencialidades e limitações. A inventariação consiste, segundo Pereira (2010), em um levantamento, avaliação e catalogação, seguida da descrição minuciosa dos bens ou locais de interesse de um determinado local.

Muitos trabalhos já realizaram a inventariação do geopatrimônio em diversas áreas costeiras. No Brasil destacamos trabalhos de inventariação do geopatrimônio realizados na região nordeste como Lopes, Araújo e Nascimento (2012); Pereira, Cunha e Nascimento (2018); Silveira, Bastos e Meira (2018) e Silva (2018); Silva, Nascimento e Mansur (2019). Estes trabalhos vêm sendo essenciais para a gestão de recursos da geodiversidade costeira, principalmente no que se refere as estratégias de geoconservação. Neste trabalho, apresentaremos a inventariação de geossítios e sítios da geodiversidade costeiros presentes no setor sudeste da Ilha do Maranhão, que abrange os municípios de São Luís e São José de Ribamar, localizado no Estado do Maranhão na região nordeste do país. 
A área possui um ambiente costeiro de dinâmica peculiar com a presença de planícies flúvio-marinhas, tabuleiros, falésias e praias arenosas que possuem valor estético acentuado e são de suma importância para ecossistema local, visto que nestas áreas são executadas atividades humanas relacionadas principalmente a agricultura e extração mineral, que utilizam diretamente do potencial da geodiversidade local.

O setor costeiro sudeste da Ilha do Maranhão é um dos setores de expansão urbana da Ilha e apresenta poucos estudos que falam sobre a geodiversidade costeira do local. Este estudo teve como objetivo fazer a inventariação e descrição ambiental sumária de geossítios e sítios da geodiversidade deste ambiente costeiro, de acordo com a classificação de Brilha (2016). A inventariação dos geossítios e sítios da geodiversidade do local pode vir a contribuir com futuros estudos relacionados ao planejamento e gestão costeira da área e a conservação da geodiversidade da área, potencializando o uso sustentável de pontos prioritários.

\section{ÁREA DE ESTUdO}

O setor costeiro sudeste da Ilha do Maranhão abrange partes do município de São Luís e do município de São José de Ribamar (Figura 1), com uma área total de $74 \mathrm{Km}^{2}$, segundo a delimitação proposta pelo Projeto GEOILHA. A área está localizada ente as coordenadas geográficas $2^{\circ} 37^{\prime} 55.26^{\prime \prime} \mathrm{S}$ e 448'2.67’O

Figura 1 - Localização do setor costeiro sudeste da Ilha do Maranhão

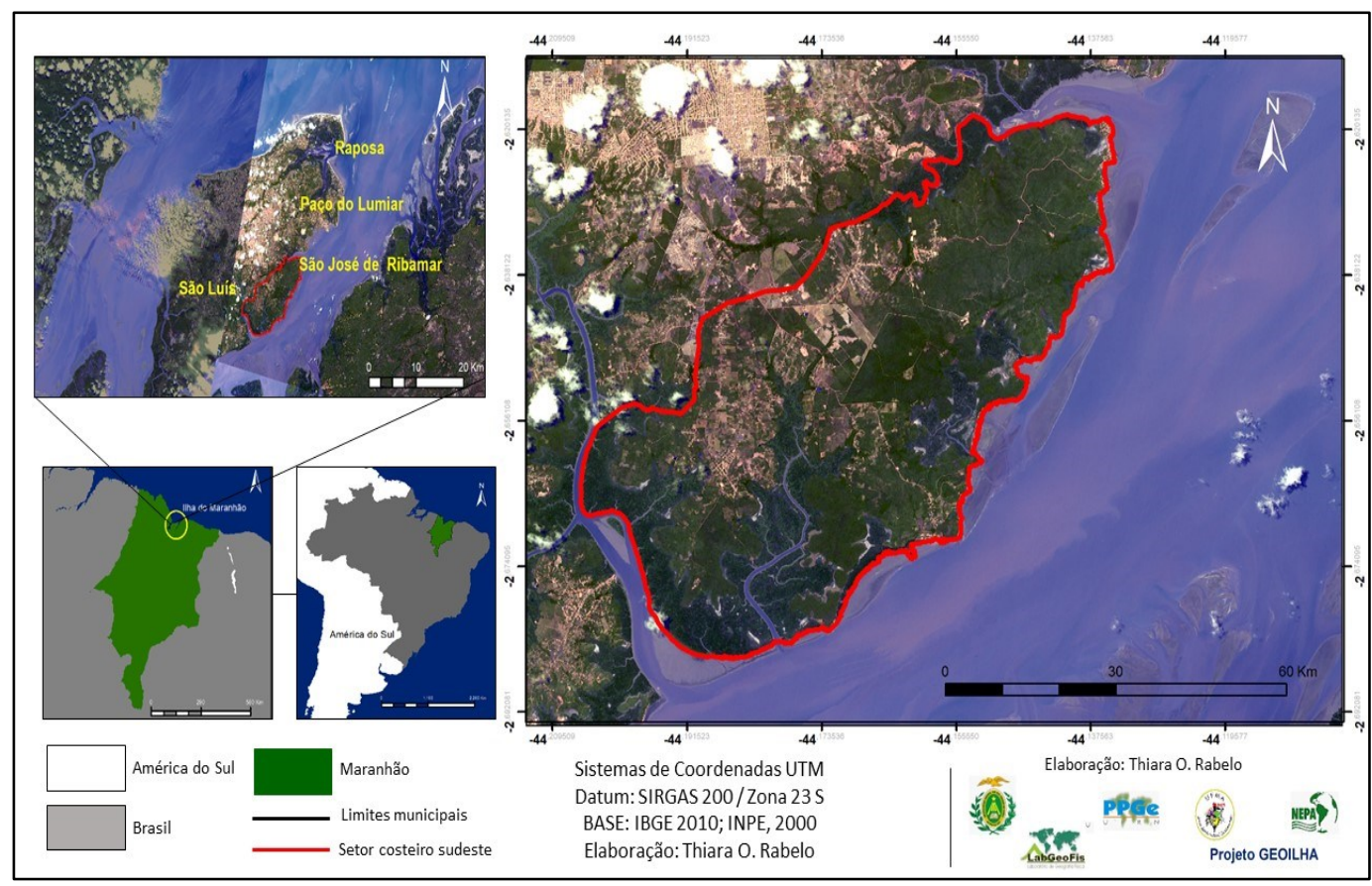

Fonte: Elaborado pelos autores. 
A área é apontada por autores como Reis (2005), Lago (2012) e Rabelo (2018) como um dos setores de expansão urbana da Ilha do Maranhão, visto que o território do município de São Luís, capital do Estado, e sua área de entorno estão acentuadamente ocupados devido o processo de ocupação desordenada influenciado pela ocupação de grandes projetos industriais no Maranhão oriundos de empresas como a VALE, ALUMAR e o mais recente projeto de uma Refinaria Premium.

O setor sudeste da Ilha é composto no que se refere a geologia pelos sedimentos da Formação Barreiras, Depósitos de Pântanos e Mangues e por Depósitos litorâneos; no que se refere a geomorfologia destacamos a presença de tabuleiros costeiros, planícies flúvio-marinhas e planícies costeiras, segundo a classificação da CPRM (2013). Estas características foram as que mais se destacaram na indicação de geossítios/sítios da geodiversidade da área.

\section{METODOLOGIA}

A inventariação dos geossítios e sítios da geodiversidade do setor costeiro sudeste da Ilha do Maranhão foi feita com base em um inventário de reconhecimento, de acordo com a proposta de Sharples (2000), tendo como base as seguintes etapas metodológicas:

1 - Pré-definição de áreas prioritárias da geodiversidade na área de estudo utilizando os trabalhos de Feitosa (2006), Klein e Souza (2012); Bandeira (2013); Silva (2012), Rabelo (2018);

2- Identificação e espacialização cartográfica de possíveis geossítios e sítios da geodiversidade tendo como base os dados do mapeamento geodiversidade do Estado do Maranhão realizado pela Companhia de Serviço Geológico do Brasil (CPRM) e organizado por Bandeira (2013); e dados do trabalho de Rabelo (2018) voltado para a geodiversidade do setor sudeste da Ilha do Maranhão, possibilitando assim a espacialização cartográfica das unidades geomorfológicas 3 - Trabalhos de campo realizados nos meses de julho de 2017 e dezembro de 2017 com uso de uma ficha de inventariação de geossítios e sítios da geodiversidade adaptada dos trabalhos de Brilha (2005) e Rabelo (2018), sendo possível avaliar em campo os seguintes critérios nas áreas inventariadas: localização geográfica, enquadramento geológico e geomorfológico geral, estatuto legal, aproveitamento do terreno, tipo de interesse do local, a caracterização do ambiente praial onde aquele geossítio/sítio da geodiversidade se encontra. Estes critérios na ficha inventariação apresentam subcritérios que foram essenciais para a inventariação dos locais e estão apresentados no quadro 01. 
Quadro 01 - Principais critérios e subcritérios utilizados para inventariação dos geossítios/sítios da geodiversidade costeiros da área em estudo

\begin{tabular}{|c|c|}
\hline Critérios & Sub-critérios \\
\hline Localização geográfica & $\begin{array}{l}\text { Coordenadas; acesso; comunidade mais } \\
\text { próxima; acessibilidade. }\end{array}$ \\
\hline Enquadramento geológico & Ambiente geológico dominante \\
\hline Avaliação preliminar & $\begin{array}{l}\text { Magnitude do local; condições de } \\
\text { observação; vulnerabilidade. }\end{array}$ \\
\hline Estatuto legal & $\begin{array}{c}\text { Área submetida a proteção; Local sensível a } \\
\text { divulgação; Nível de urgencia em promover } \\
\text { a proteção. }\end{array}$ \\
\hline Aproveitamento do terreno & $\begin{array}{l}\text { Rural, florestal, agrícola, etc.; situação } \\
\text { administrativa; Obstáculos para } \\
\text { aproveitamento do terreno. }\end{array}$ \\
\hline Tipo de interesse do local. & $\begin{array}{l}\text { Pelo conteúdo; pela possível utilização; pela } \\
\text { sua influencia a nivel local, regional, } \\
\text { nacional e internacional. }\end{array}$ \\
\hline Caracterização do ambiente praial & $\begin{array}{l}\text { Presença de erosão ou deposição; } \\
\text { Interferência antrópica, Presença de } \\
\text { vegetação; Presença de dunas; Estruturas } \\
\text { sedimentares; Tipo de sedimentos. }\end{array}$ \\
\hline
\end{tabular}

Fonte: Elaborado pelos autores com base em Brilha (2005) e Rabelo (2018).

4 - A espacialização definitiva dos locais deu-se após a etapa de campo de inventariação usando o Software ArcGis 10.9, de imagens de satélite de alta resolução (SPOT) cedidas pela coordenação do projeto GEOILHA. Nesta pesquisa foi possível inventariar e mapear 8 geossítios/sítios da geodiversidade localizados na planície costeira do setor sudeste da Ilha do Maranhão.

A inventariação dos locais indicados nesta pesquisa teve como principais critérios de escolha os atributos geológicos e geomorfológicos mais representativos da área que apresenta formas e dinâmicas costeiras diferenciadas em comparação com o litoral ocidental da Ilha, apresentando-se como uma potencialidade importante da geodiversidade nesse setor.

\section{A GEODIVERSIDADE DO SETOR COSTEIRO SUDESTE DA ILHA DO MA}

O setor costeiro sudeste da Ilha do Maranhão, está inserido em uma área de clima equatorial chuvoso, com predominância de chuvas entres os meses de janeiro a maio. É essencialmente formada por rochas sedimentares de textura arenoargilosa, com relevos que compreendem principalmente áreas tabulares, planícies flúvio-marinhas e planícies costeiras que dão origem a solos não tão profundos e de média fertilidade natural (RABELO, 2018). 
O quadro 02 apresenta de forma objetiva as principais características observadas na geodiversidade da área no que se refere a geologia e geomorfologia, que foram os principais elementos considerados para inventariação da geodiversidade costeira desta área.

Quadro 2 - Síntese das características das unidades geológicas e geomorfológicas presentes na área em estudo.

\begin{tabular}{|c|c|c|}
\hline Elementos & Tipologias & Caracterização \\
\hline \multirow{3}{*}{ Geologia } & Formação Barreiras & $\begin{array}{l}\text { Composta por arenitos mal } \\
\text { selecionados, finos a } \\
\text { grossos, variegados, em } \\
\text { geral, argilosos com } \\
\text { numerosas intercalações de } \\
\text { folhelhos. Em alguns locais } \\
\text { destas áreas, os sedimentos } \\
\text { encontram-se bastante } \\
\text { intemperizados, } \\
\text { ferruginizados e laterizados. }\end{array}$ \\
\hline & $\begin{array}{c}\text { Depósitos de pantânos e } \\
\text { mangues }\end{array}$ & $\begin{array}{c}\text { Estes depósitos são } \\
\text { constituídos, } \\
\text { predominantemente, por } \\
\text { sedimentos lamosos (argila e } \\
\text { silte), de coloração cinza, e } \\
\text { não adensados. Esta unidade } \\
\text { geológica abrange grande } \\
\text { parte das bacias } \\
\text { hidrográficas da área. }\end{array}$ \\
\hline & Depósitos litorâneos & $\begin{array}{l}\text { Estes depósitos, possuem } \\
\text { formação recente, } \\
\text { compostos por areias } \\
\text { quartzosas de granulometria } \\
\text { muito fina a fina. }\end{array}$ \\
\hline \multirow[t]{2}{*}{ Geomorfologia } & Tabuleiros costeiros & $\begin{array}{l}\text { Feição predominante na área } \\
\text { com formas de relevo } \\
\text { suavemente dissecado, topos } \\
\text { planos, alongados e } \\
\text { vertentes retilíneas. Estes } \\
\text { tabuleiros encerram-se em } \\
\text { sua maioria em falésias } \\
\text { ativas, principalmente nas } \\
\text { áreas de domínio das } \\
\text { planícies costeiras }\end{array}$ \\
\hline & & $\begin{array}{l}\text { Ocorrem em todo o litoral } \\
\text { do setor sudeste, com maior } \\
\text { representatividade na porção } \\
\text { centro-sul, localizado na foz }\end{array}$ \\
\hline
\end{tabular}




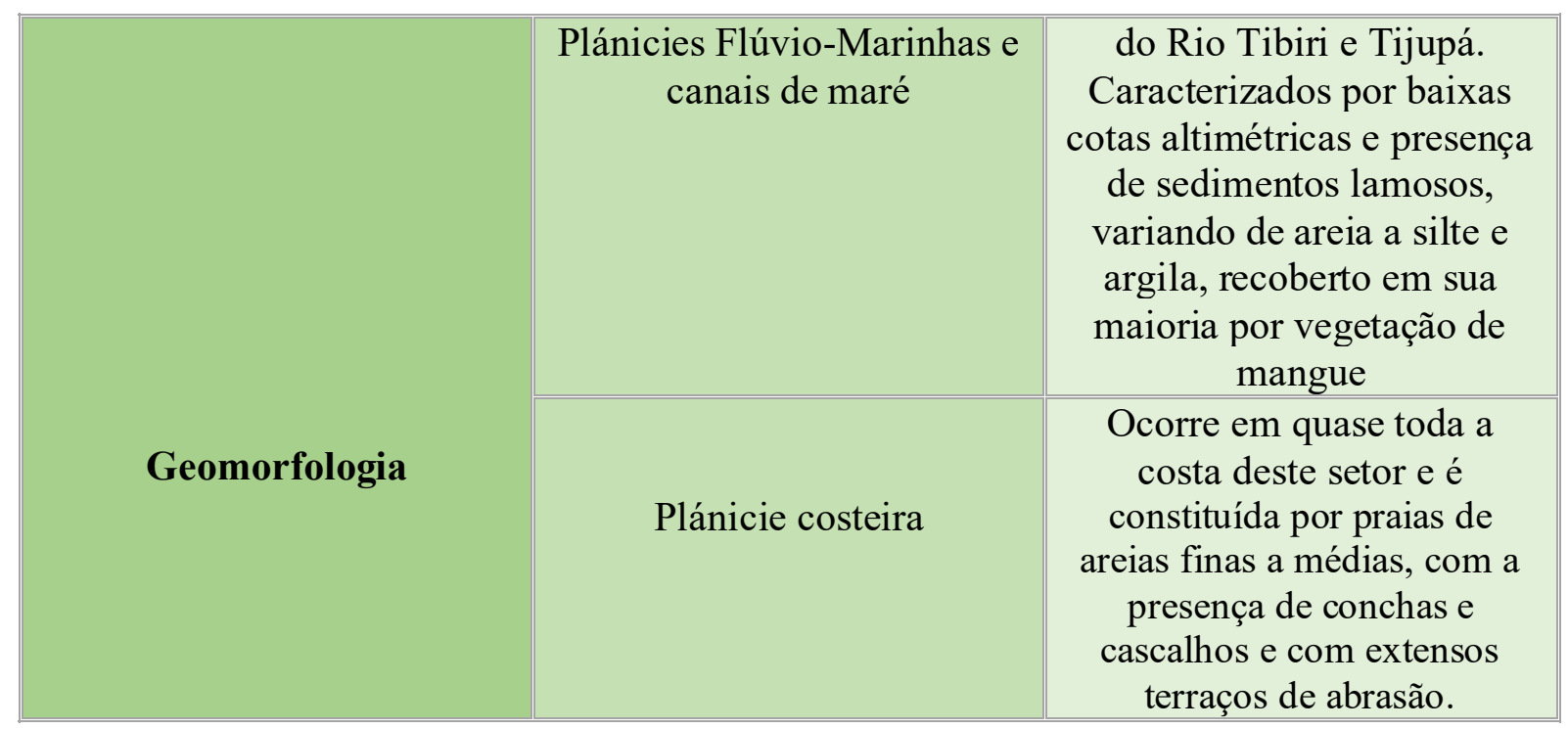

Fonte: Elaborado pelos autores a partir de Rabelo (2018)

No que se refere a dinâmica de ventos, Rodrigues (2006) afirma que esta área apresenta uma média anual de $5,28 \mathrm{~m} / \mathrm{s}$ para a parte costeira do município de São José de Ribamar. Rabelo (2018) destaca que na área em estudo a ação eólica não exerce um papel de grande relevância, pois os ventos são de baixa intensidade visto que não há a presença de feições geomorfológicas como dunas, que são formadas em áreas onde a ação dos ventos são mais intensas, como é possível observar no litoral ocidental da Ilha do Maranhão.

A área é apresenta também um regime de macro-marés com amplitudes superiores a 4 metros variando até 06 metros, de acordo com Rodrigues (2006) e ondas do tipo deslizantes, visto que o grau de inclinação da praia é muito plano, fator que facilita a ocorrência de terraços de abrasão na área.

\section{RESULTADOS}

Inventariação dos geossítios/ sítios da geodiversidade do setor costeiro sudeste da Ilha do MA

Além das potencialidades das características geológicas e geomorfológicas do setor sudeste da Ilha do Maranhão outro fator que influenciou o processo de inventariação destas áreas foram as limitações observadas no local. A área constitui-se como naturalmente frágil, de acordo com o método de estudo da morfodinâmica de Tricart (1977), devido está em uma zona de transição entre o mar, o continente e a atmosfera e apresenta sujeição a inundação diárias em decorrência da dinâmica de marés e sedimentos poucos consolidados com pouca capacidade de suporte quando submetidos a carga elevada. 
Foram inventariados 8 locais no setor sudeste da Ilha do Maranhão, sendo eles: Ponta de Juçatuba, Praia de Juçatuba, Praia da Moça, Morro do Pelado, Praia de Catatiua, Praia de Guarapiranguinha e Praia de Guarapiranga (Figura 2). Todos os pontos inventariados foram classificados como geossítios visto que apresentaram valor científico a partir da inventariação feita nesta pesquisa e também foram classificados como sítios da geodiversidade posto que foram encontrados associados valores econômico, didático e turístico aos locais.

Figura 2 - Localização dos geossítios/sítios da geodiversidade inventariados na área

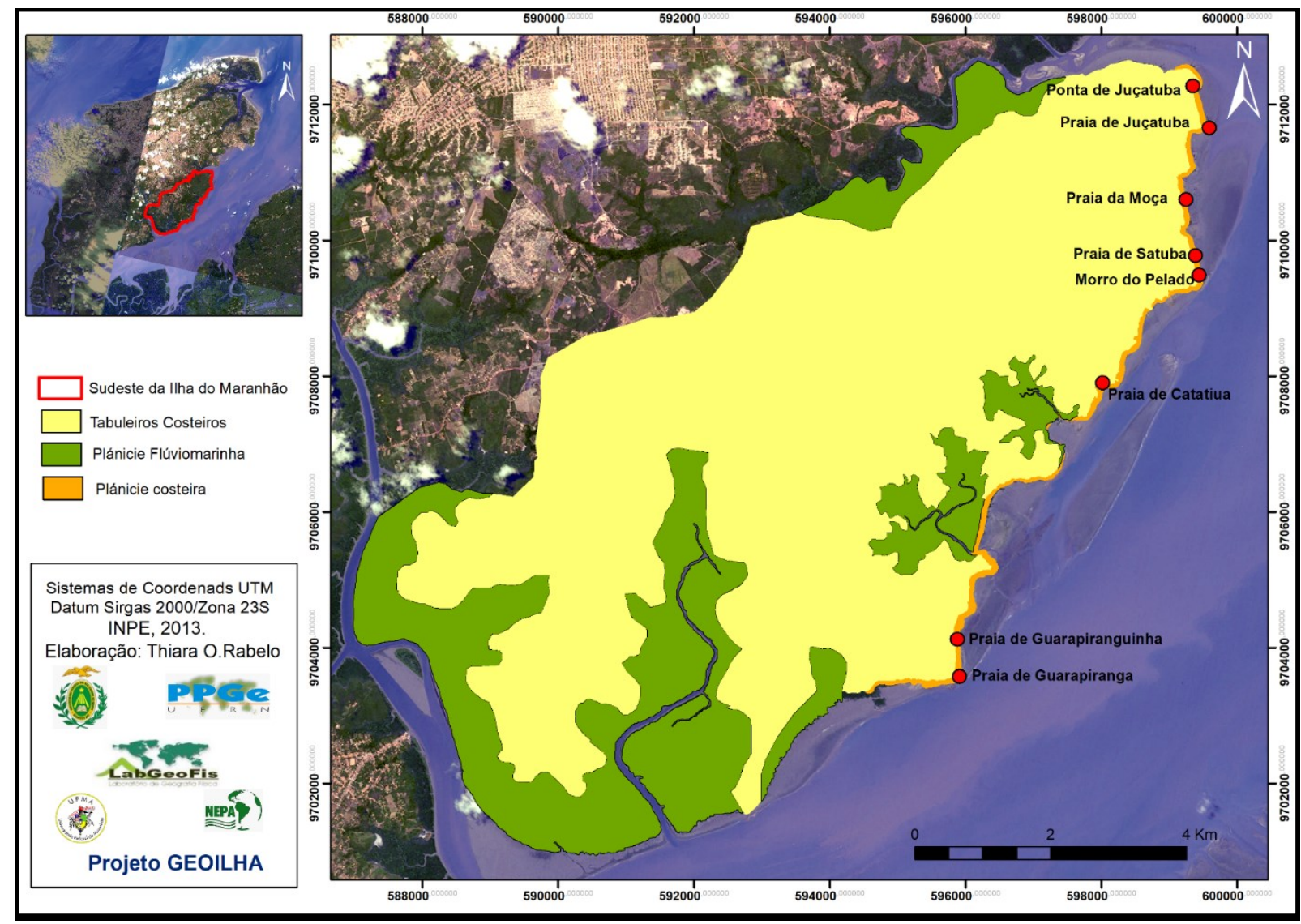

Fonte: Rabelo (2018).

A) Ponta de Juçatuba

Está localizado nas coordenadas $2^{\circ} 36^{\prime} 8.09^{\prime \prime}$ S e $44^{\circ} 6^{\prime} 21,55^{\prime \prime}$ e encontra-se situada no município de São José de Ribamar - MA (Figura 3). A ponta de Juçatuba é um dos locais mais conhecidos por visitantes deste setor na Ilha do MA principalmente por sua acessibilidade e pela presença de pousada e restaurante no local, além de encontra-se em um dos pontos mais altos da área, apresentando cerca de 15 metros de elevação, o que possibilita uma visualização ampla de grande parte da paisagem deste setor costeiro. 
Figura 3 - Vista da Ponta de Juçatuba no setor sudeste da Ilha do MA

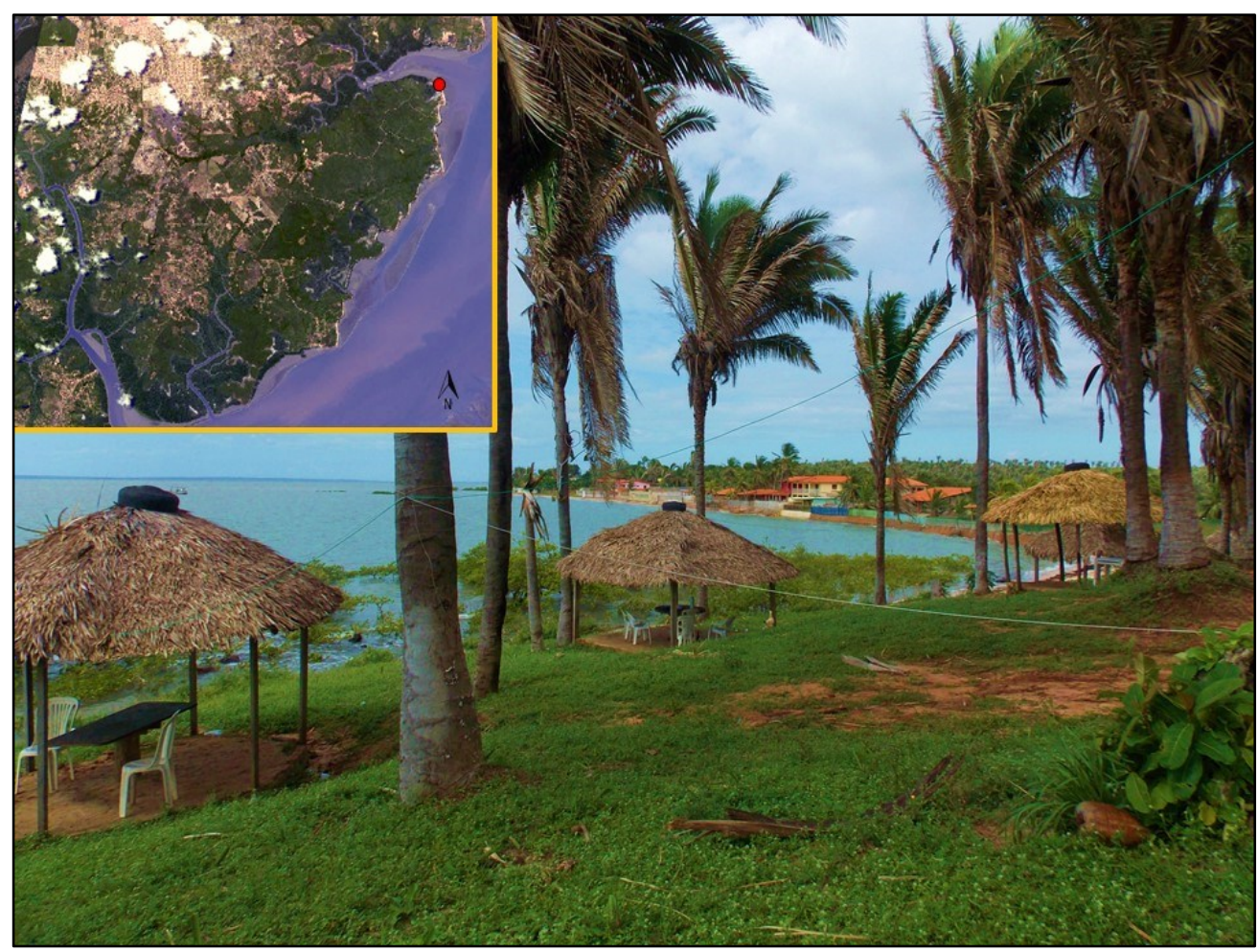

Fonte: Acervo da pesquisa.

Segundo Rabelo (2018), este local é basicamente composto por depósitos litorâneos e arenitos ferruginosos da Formação Barreiras provenientes das áreas tabulares deste setor e que estão presentes tanto na parte mais elevada quanto na base deste setor, que já possui contato direto com o mar em períodos de macro-marés e acentuam o processo de intemperismo no local.

Desta forma, vale ressaltar que este local está inserido em uma área de alta vulnerabilidade devido está localizado em uma área de intensa dinâmica costeira, porém este ponto apresenta um pequeno terraço de abrasão e restos de vegetação de mangue em sua parte inferior, sendo estes fatores que atenuam o processo de erosão que está ocorrendo neste ponto, ocasionado principalmente pela ação das ondas.

Este geossítio não está submetido a nenhuma categoria de proteção legal e segundo Rabelo (2018), a proximidade deste local com algumas comunidades da área e a falta de coleta regular de lixo potencializam o acúmulo de resíduos sólidos deixados no local com aqueles que já são trazidos pela água do mar. 
A vista proporcionada da Ponta de Juçatuba de todo o litoral do setor sudeste da Ilha do Maranhão e do município de São José de Ribamar, além de sua proximidade com a Praia de Juçatuba, e por ser um local com preparado com estrutura como pousada e restaurante favorecem o aproveitamento do terreno para o uso turístico do local e reforçam o valor científico e didático da área.

\section{B) Praia de Juçatuba}

A praia de Juçatuba está localizada no município de São José de Ribamar - MA entre as coordenadas $2^{\circ} 36^{\prime} 28.24^{\prime \prime} \mathrm{S}$ e $44^{\circ} 6^{\prime} 17.76^{\prime \prime} \mathrm{W}$ e é um dos locais mais conhecidos e visitados deste setor devido a sua proximidade com a Ponta de Juçatuba (Figura 4) que apresenta estruturas para o recebimento de visitantes e fácil acessibilidade a partir de avenidas asfaltadas.

Figura 4 - Praia de Juçatuba localizada no setor sudeste da Ilha do Ma.

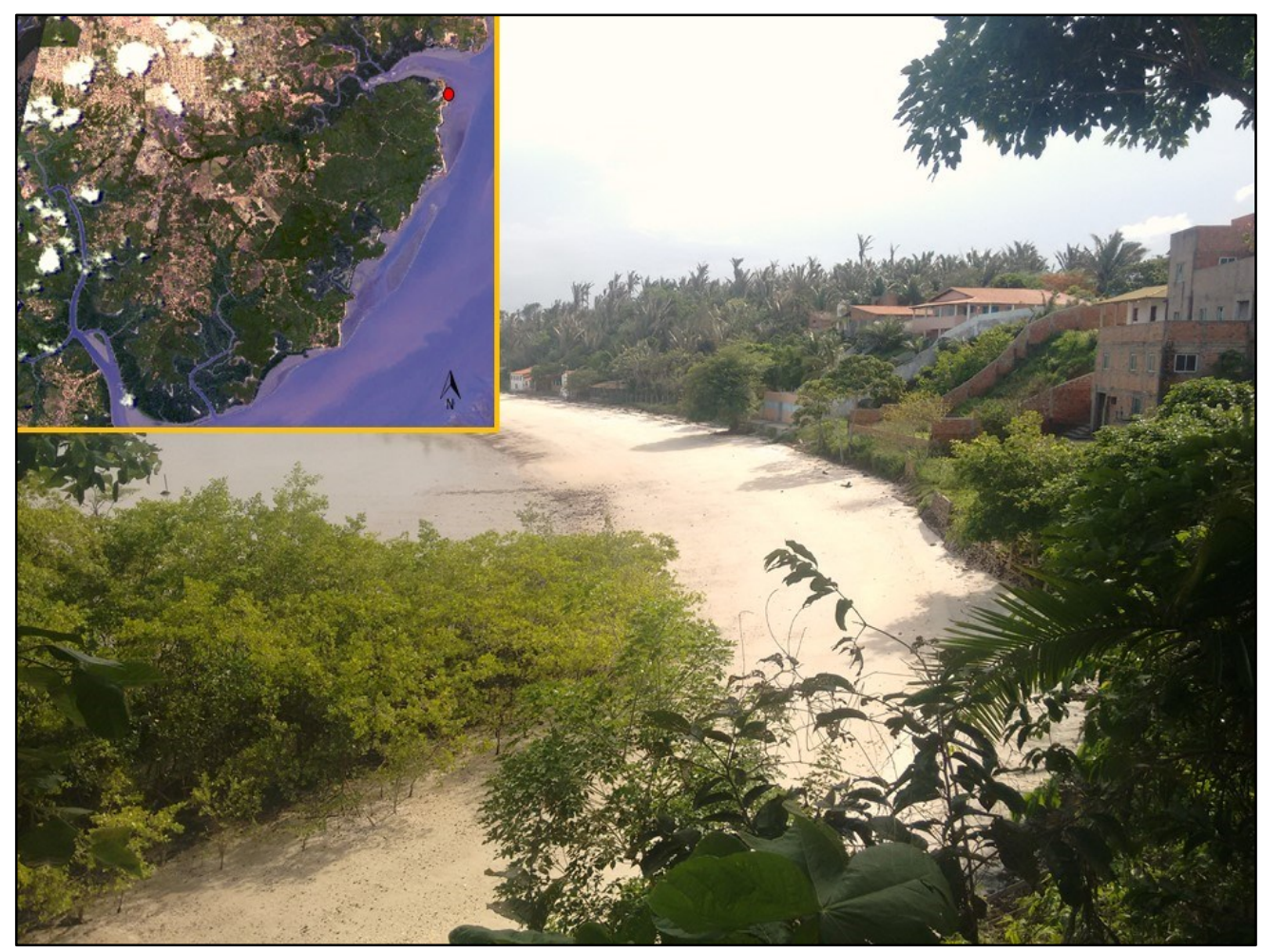

Fonte: Acervo dos autores.

Rabelo (2018) afirma que este local apresenta como base geológica os depósitos litorâneos e está inserido totalmente na área da planície costeira com elevação que varia de 2 a 5 metros de linha de costa, possui perfil dissipativo apresentando topografia plana e com baixa variação altimétrica. É importante ressaltar, que diferente das demais praias deste setor, a praia de Juçatuba não se encontra rodeada por falésias, mas apresenta um extenso terraço de abrasão.

Este terraço de abrasão estende-se por 21 metros de comprimento até antes de iniciar a zona de ante-praia, segundo Rabelo (2018), e é formado neste local principalmente por 
argilitos ferruginosos que são recobertos por crustáceos marinhos da classe Círripédia $s p$ (ordem Sessilia), conhecidos popularmente como cracas e também restos de vegetação de mangue, justificando-se os valores científicos e didáticos da área.

Este ponto não está submetido a nenhuma categoria de proteção legal e encontra-se em um ambiente de alta vulnerabilidade devido a dinâmica costeira do local e presença humana no local. Nesta praia há a presença de casas inseridas na zona de pós-praia e foi observada a presença de muros de contenção em todas as residências com sinais de destruição de ondas em algumas estruturas.

De acordo com Rabelo (2018) o local não é adequado para a fixação de obras de engenharia, pois é constituído por um terreno de granulometria fina e com pouca sustentação geológica. A praia de Juçatuba é uma das praias que mais recebem visitantes na área segundo Rabelo (2018). Suas características naturais, sua proximidade a ponta de Juçatuba e a maior ocupação humana próximo a este local fazem com este local apresente também valor turístico.

C) Praia da Moça

Esta praia está localizada no município de São José de Ribamar entre as coordenadas $2^{\circ} 37^{\prime} 0.05^{\prime}$ S e 44 6’ 27,30" W (Figura 5). A divulgação dessa praia é praticamente incipiente se comparada aos demais pontos deste setor, sendo mais conhecida apenas por moradores mais próximos do local e por pescadores que vem da sede do município de São José de Ribamar para pescar neste local.

Figura 5 - Praia da moça localizada no setor sudeste da Ilha do MA

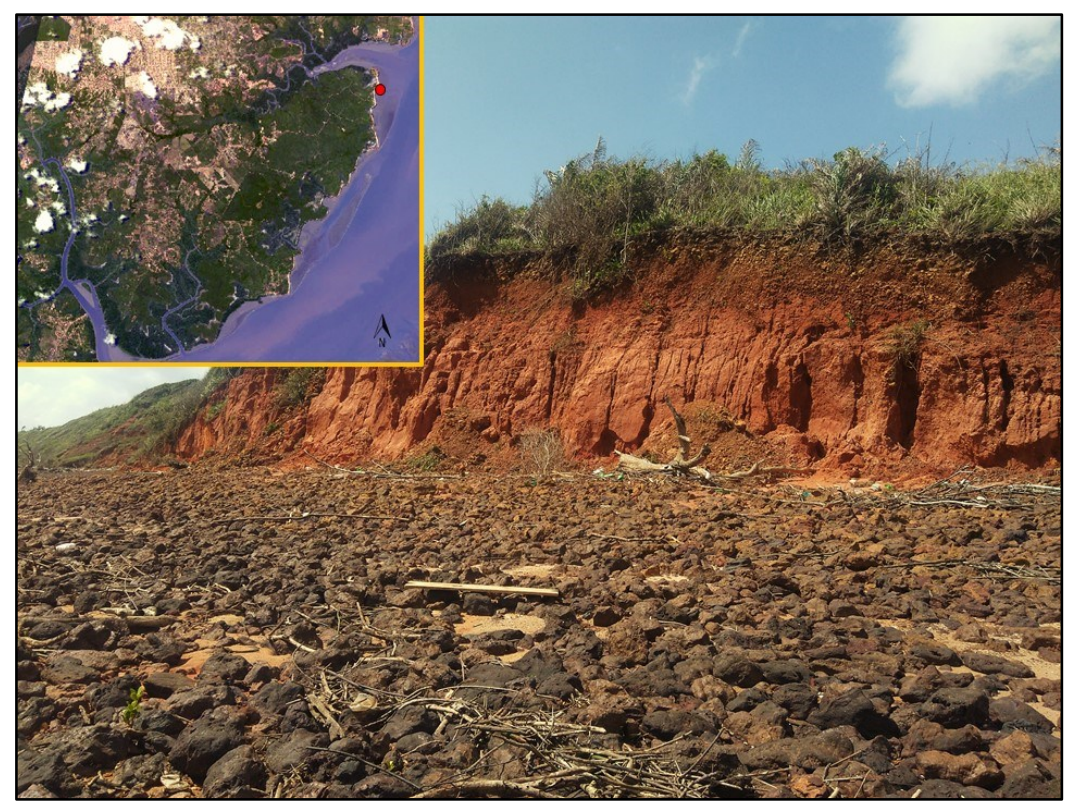

Fonte: Acervo dos autores 
Rabelo (2018) afirma que a praia da Moça está situada em uma área plana, porém com cotas de elevação que variam de 3 a 6 metros e apresenta perfil dissipativo com sedimentos de granulometria fina e também é composta por uma área com extensas camadas litológicas intemperizadas paralelas à linha de costa que se alternam entre lamitos de matriz clastosuportada homogêneos de coloração vermelho-escuro e lamitos de matriz suportada heterogêneo de coloração vermelho claro e amarelo.

$\mathrm{Na}$ área é possível observar a presença de um paredão de falésias que apresentam cerca de 13 a 15 metros de altura e segundo Rabelo (2018), estas falésias são homogêneas e possuem em seu topo solo residual de coloração vermelha desenvolvido com cerca de 1,5 m de espessura. Estas feições são formadas em seu topo por rochas do tipo argilitos ferruginosos e em sua base por argilitos ferruginosos.

É importante ressaltar que o local não está submetido a nenhuma categoria de proteção legal e devido fazer parte da zona costeira e apresentar uma dinâmica instável devido a estar localizado na interface mar, continente e oceano, este local apresenta um grau alto de vulnerabilidade. Além de valor científico, a praia da Moça apresentou também valor didático visto que é uma área onde facilmente possível a observação em aulas e pesquisas de campo da dinâmica de ondas, diferenciação das camadas litológicas, ocorrência de terraço de abrasão, diferentes ações de intemperismo costeiro e erosão.

\section{D) Praia de Satuba}

A praia de Satuba está situada no município de São José entre as coordenadas $2^{\circ} 37^{\prime}$ 15.09" S e 44 6' 27.73" e possui pouca divulgação de sua localização para turistas e visitantes, sendo mais conhecida por moradores da área. A praia apresenta perfil dissipativo devido a sua topografia plana e possui pouca variação altimétrica o que contribui para formação de ondas do tipo deslizante.

Nesta área são encontrados sedimentos de granulometria média a fina e é possível observar a presença de minerais pesados. Rabelo (2018) afirma que ao longo do estirâncio desta praia além de um extenso terraço de abrasão (Figura 6) é possível observar área onde encontramos rochas do tipo lamito matriz de alta maturidade textural e composicional, heterogêneo e com tonalidades variando entre o cinza claro a vermelho. Em alguns pontos da praia estas rochas encontram-se soterradas ou com a porção superior à mostra e geralmente em cores que variam do preto ao amarelo por se encontrar em processo pedogenético ou em intemperismo químico ativo. 
Figura 6 - Vista da praia de Satuba no setor sudeste da Ilha do Maranhão

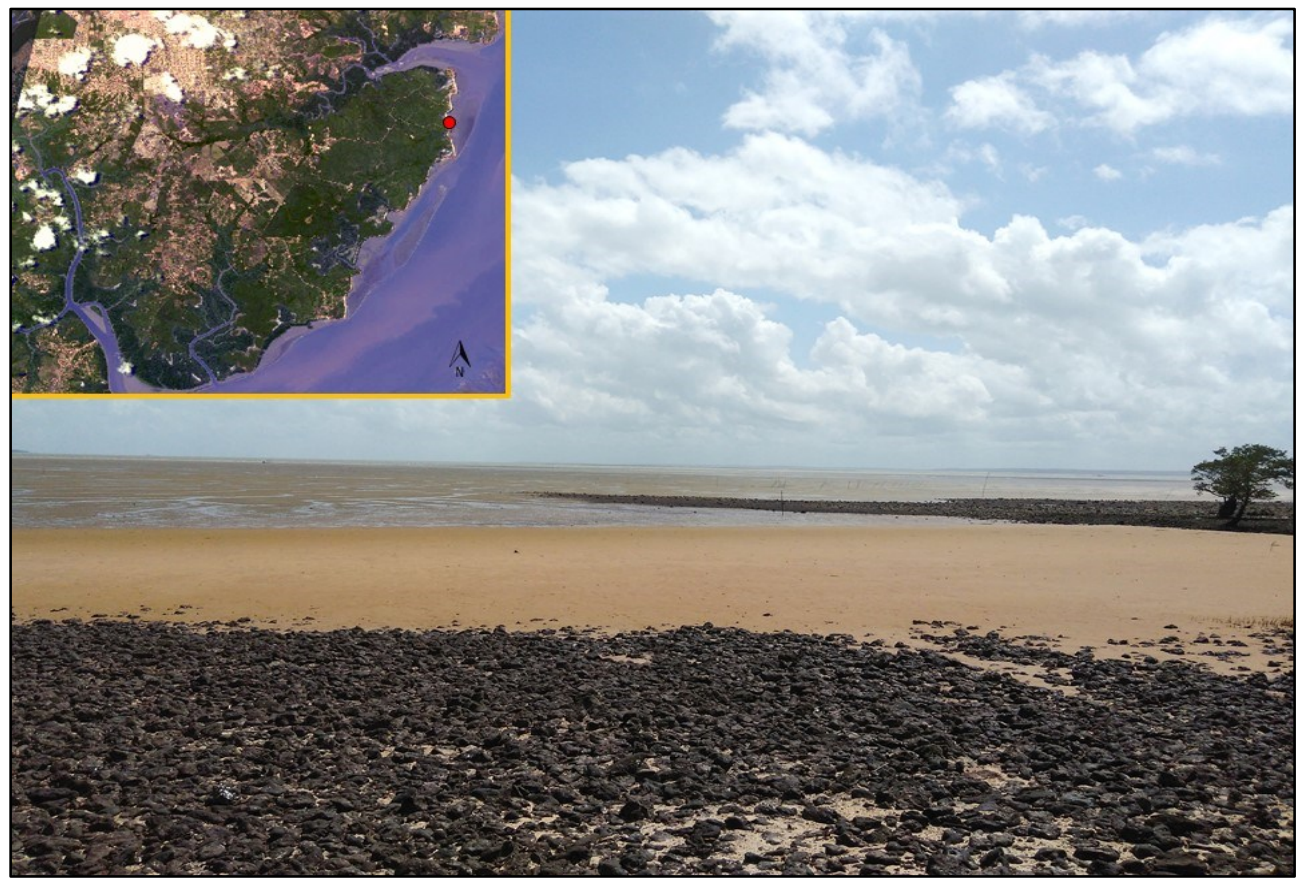

Fonte: Acervo dos autores.

A área também não está submetida a nenhuma categoria de proteção legal e apresenta alta vulnerabilidade costeira. Uma característica destacada por Rabelo (2018) é que esta praia apresenta camadas litológicas de arenitos ferruginosos em direção perpendicular à linha de costa, diferente das demais praias da Ilha do Maranhão onde estas camadas litológicas são paralelas à linha de costa. A praia de Satuba também rodeada por falésias que variam entre 18 a 20 metros de altura.

Considerando as características geológicas e geomorfológicas presentes neste ponto podemos considerar que a praia de Satuba possui potencial principalmente para uso didático e científico devido s feições diferenciadas que existem na área e por ainda não ter tantos estudos voltada para esta praia. O local também possui potencial para o lazer e uso turístico porém, por conta da pouca divulgação ainda é pouco utilizado para estes fins.

\section{E) Morro do Pelado}

Este ponto está localizado muito próximo ao fim da praia de Satuba, há cerca de $1 \mathrm{~km}$ desde o ponto inicial da praia e está localizado entre as coordenadas $2^{\circ}{ }^{`} 37^{\prime} 42.74^{\prime}$ ' S e $44^{\circ} 6^{\prime}$ ' 19.88” W. O Morro do Pelado apresenta 18,5 metros de altura e é sensível a pouca divulgação, sendo conhecido apenas por moradores que possuem residências próximo à praia de Satuba e 
por pescadores que utilizam o morro como referência quando estão voltando de pescarias em alto-mar (Figura 7).

Figura 7 - Morro do Pelado localizado no setor costeiro sudeste da Ilha do MA

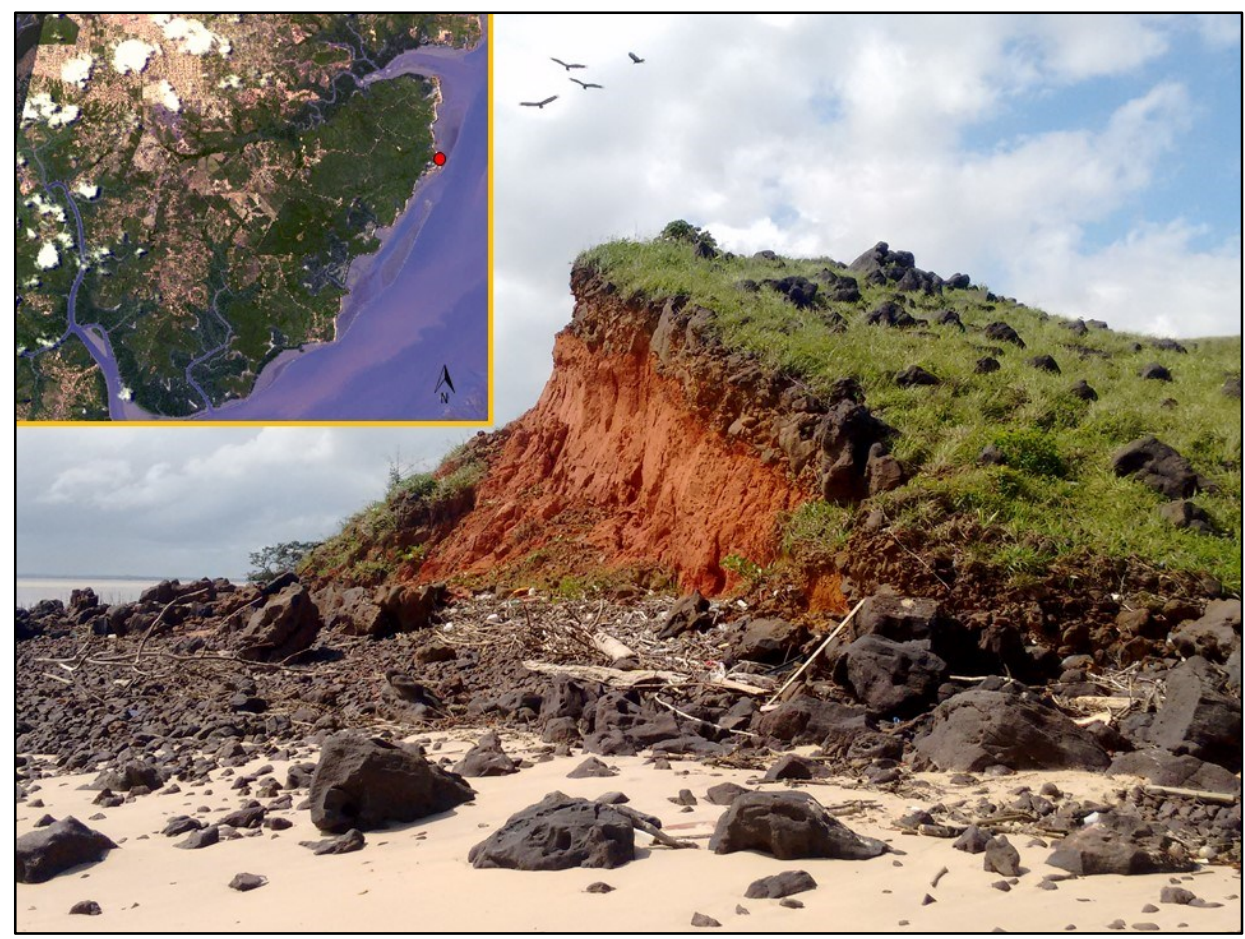

Fonte: Acervo dos autores.

O Morro do Pelado configura-se como um morro testemunho visto que possui características de relevo residual em uma área de superfície mais plana ao redor. Rabelo (2018) destaca que o morro é formado por rochas sedimentares siliciclásticas classificadas como arenitos ferruginosos e embora esteja em uma área de alta vulnerabilidade ambiental, a base do morro em questão é protegida por um terraço de abrasão formado cascalhos e que protegem este ponto de uma erosão mais acentuada causada pelas ondas do mar.

Este local, assim como maior parte dos locais inventariados da área, não está submetido a nenhuma categoria de proteção legal. As características geomorfológicas observadas no local destacam o valor científico e didático do Morro do Pelado, além de se constituir como forma geomorfológica atrativa para futuro desenvolvimento do geoturismo na área.

\section{F) Praia de Catatiua}

Esta praia também está localizada no município de São José de Ribamar e encontra-se entre as coordenadas $2^{\circ} 38^{\prime} 34.56^{\prime}$ S e $44^{\circ} 7^{\prime} 7.57^{\prime}$ O (Figura 8), situada entre a Ponta de 
Juçatuba e a Ponta de Guarapiranga e é conhecida principalmente por pescadores que ali fazem seus ranchos em períodos de pescaria e afirmam que a utilizam também como espaço de lazer com suas famílias nestes períodos e por poucas pessoas que possuem residência fixa no local.

Figura 8 - Praia de Catatiua localizada no setor sudeste da Ilha do MA

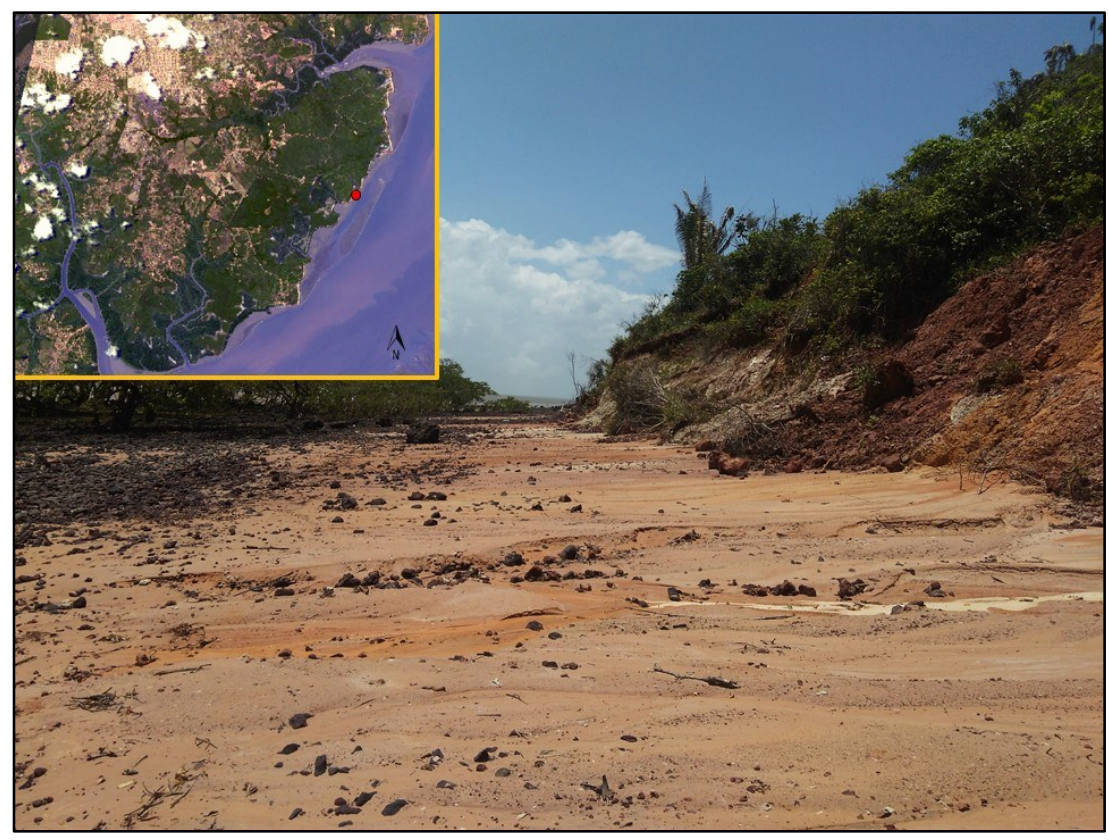

Fonte: Acervo dos autores.

Rabelo (2018) destaca que esta praia possui um dos maiores terraços de abrasão observados dentre as praias do setor sudeste, formado por arenitos ferruginosos e é cercada por um paredão de falésias de cerca de 35 a 40 metros de altura. Estas falésias apresentam variação composicional horizontal evidenciada pelas cores amarelo vermelho e branco, sendo esta última cor encontrada em sua base devido a uma camada predominante branca formada por caulim. Suas características ressaltam seu valor didático e científico.

Nessas áreas da falésia composta por caulinita é possível encontrar fontes de afloramento de água doce na base das falésias que são utilizados para suprir as necessidades básicas dos moradores locais que vão até estes pontos em busca de água. Esta praia não é submetida a nenhuma categoria de proteção legal e a pouca presença humana na área não apresenta grandes ameaças a este ambiente costeiro.

G) Praia de Guarapiranguinha

A praia de Guarapiranguinha é uma das praias que compõe a Ponta de Guarapiranga e está localizada no município de São José de Ribamar entre as coordenadas $2^{\circ} 40^{\prime} 45.58^{\prime}$ S e 
44 8'14.95"W (Figura9). Esta praia é uma das mais conhecidas deste setor e pode-se observar, principalmente aos fins de semana, a presença de visitantes e turistas neste local.

Figura 9 - Praia de Guarapiranguinha localizada no setor sudeste da Ilha do MA

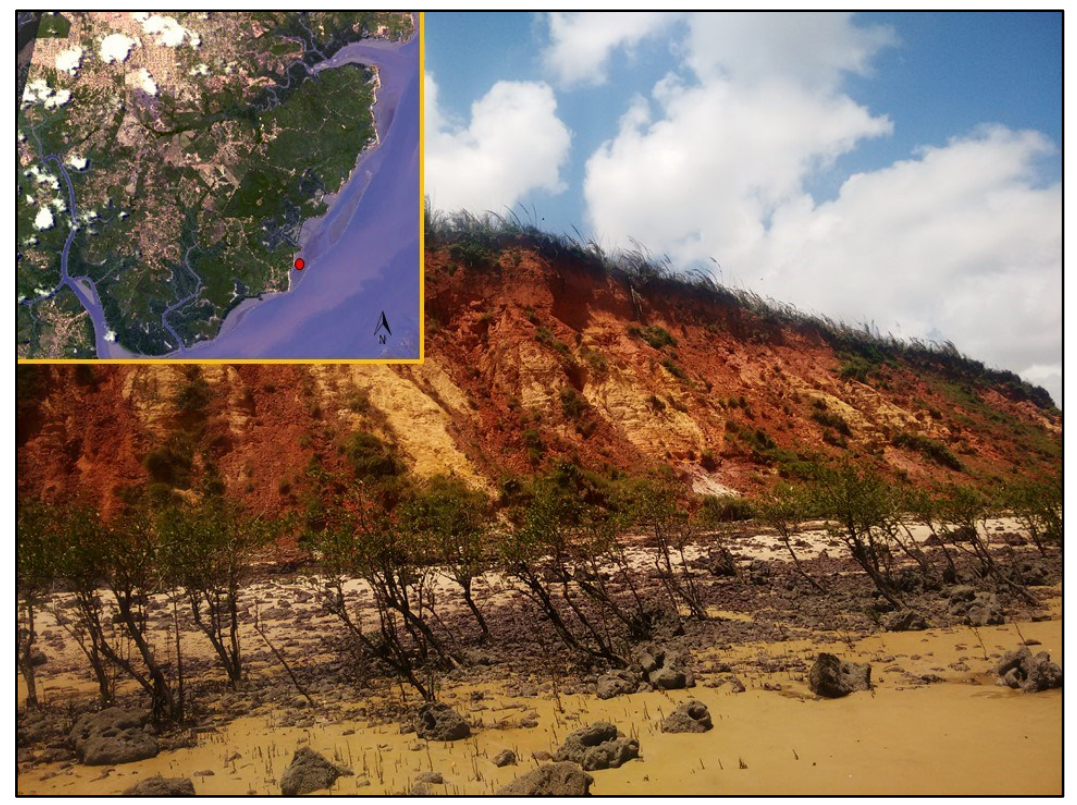

Fonte: Acervo dos autores.

Conforme afirma Rabelo (2018), esta praia é cercada por um extenso paredão de falésias com cerca de 35 a 40 metros de altura composto por rochas siliciclásticas e apresentam feições com variação composicional vertical indicada pela alternância de cores vermelho e amarelo, resultantes dos materiais oriundos do processo de pedogênese no local.

Observou-se em Guarapiranguinha um extenso terraço de abrasão que apresenta características semelhantes ao encontrado na praia de Juçatuba, sendo compostos por argilitos ferruginosos recobertos por crustáceos marinhos conhecidos popularmente como cracas. $\mathrm{Na}$ área de praia e pós-praia foram observados sedimentos com granulometria fina.

O local não está submetido a nenhuma categoria de proteção legal e em relação interferência humana na paisagem local destacamos a presença de currais para pesca e de um mirante feito de madeira pelos pescadores para servir de ponto de observação e referência para quando estiverem em alto mar. Considerando sua proximidade com a Praia de Guarapirangua, que segundo Rabelo (2018) é uma das praias mais conhecidas do setor, Guarapiranguinha recebe a visitantes de São José de Ribamar e de municípios vizinhos, ressaltando assim além do seu valor científico e didático o seu valor turístico. 


\section{H) Praia de Guarapiranga}

Em conjunto com a praia de Guarapiranguinha e praia de Guarapiranga compõe a chamada ponta de Guarapiranga neste setor e está localizada entre as coordenadas $2^{\circ} 40^{\prime} 45.58^{\prime \prime}$ $\mathrm{S}$ e $44^{\circ} 8^{\prime} 14.95^{\prime \prime} \mathrm{O}$ (Figura 10). Esta praia é uma das praias mais conhecidas deste setor apresentando inclusive placas de acesso até o local e possui a presença de alguns bares, o que contribui para a presença de visitantes nesta praia.

Figura 10 - Praia de Guarapiranga localizada no setor sudeste da Ilha do MA

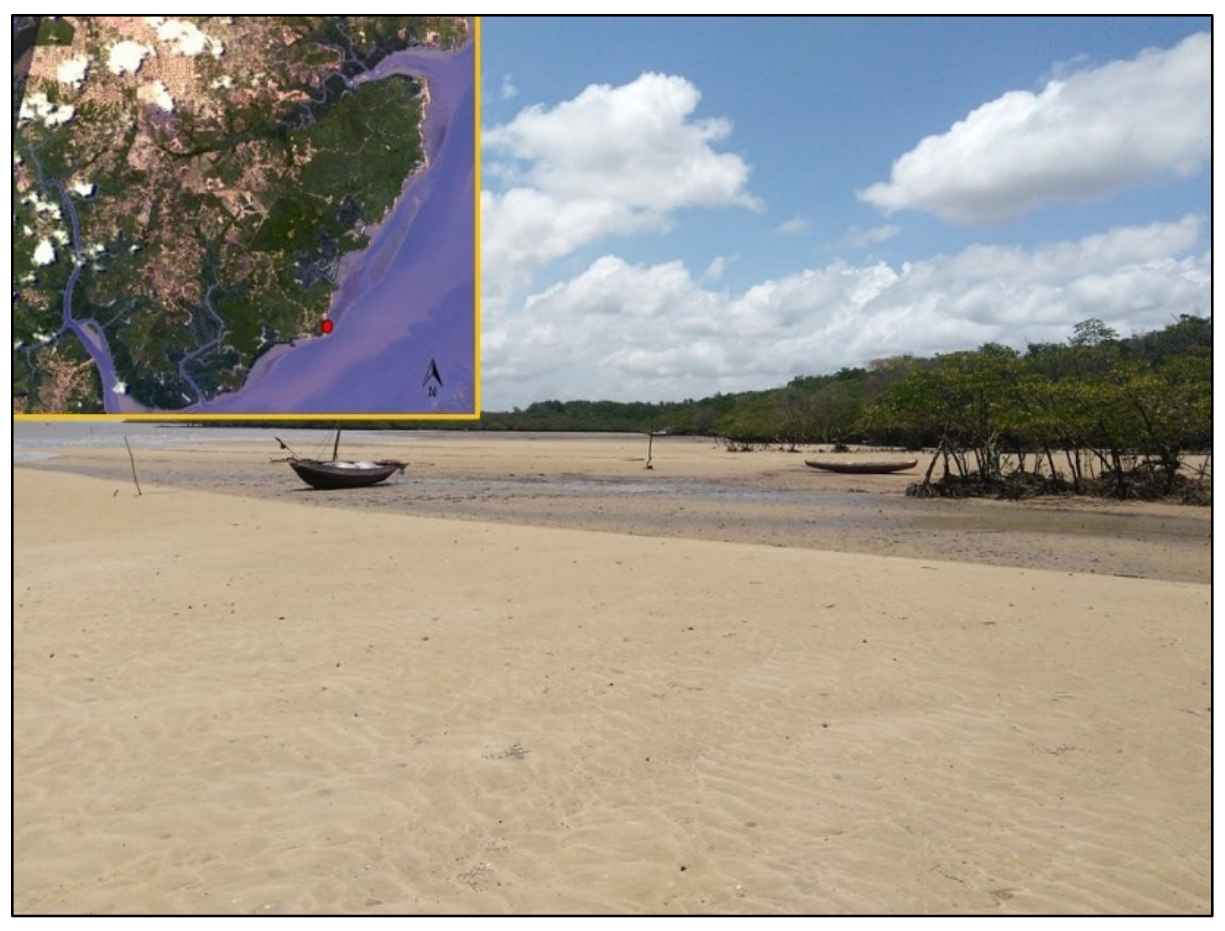

Fonte: Acervo dos autores.

Devido a sua localização já próxima a áreas de planícies flúvio-marinhas do setor é possível observar em Guarapiranga podendo ser observado acentuada presença de restos de vegetação de mangue e a presença de terraço de abrasão passando por processo de intemperismo químico e físico posto que este é atingindo pela ação das ondas e recoberto pela água do mar nas macro-marés.

Rabelo (2018), destaca que não possui a presença de falésias tão altas quanto as encontradas em Guarapiranguinha, apresentando estas feições no local cerca de 5 a 10 metros e encontrando-se estabilizadas e recobertas por vegetação, com poucas áreas expostas e tendo sua base protegida por matacões de arenitos ferruginosos. Assim como as demais praias deste setor a Guarapiranga apresenta um perfil dissipativo e possui uma extensa faixa de areia de granulometria média a fina. Essas características corroboram para a indicação dos valores científicos e didáticos da área. 
É possível observar em Guarapiranga a presença de ocupações humanas residenciais e comerciais em sua zona de pós-praia sendo importante enfatizar que o local não está submetido a nenhuma categoria de proteção legal. Observou-se na área o uso de pneus para contenção da ação da maré em algumas residências, além da presença acentuada de resíduos sólidos em comparação com as demais praias do setor. Nesta praia também foi possível observar em sua área de pós-praia a ocorrência de extração de areia para construção civil de grandes obras residenciais que estão sob nas áreas tabulares do setor. A presença de empreendimentos como bares e restaurantes colaboram para o recebimento de visitantes e turistas no local, acentuando o valor turístico do local.

\section{DISCUSSÕES}

A partir da inventariação feita dos geossítios/sítios da geodiversidade do setor costeiro sudeste da Ilha do Maranhão foi possível organizar um quadro-síntese com os aspectos relevantes da geodiversidade da área e com os principais processos e dinâmicas que podem ser observados na área e que agregam valor científico, didático e turístico ao local (Quadro 3).

Quadro 3 - Síntese das informações relevantes da geodiversidade em cada geossítio/sítio da geodiversidade inventariado.

\begin{tabular}{|c|c|c|}
\hline $\begin{array}{l}\text { Geossítios/sítios da } \\
\text { geodiversidade }\end{array}$ & $\begin{array}{l}\text { Aspecto relevante da } \\
\text { geodiversidade }\end{array}$ & Feições/Processos \\
\hline Ponta de Juçatuba & Geomorfologia & - Dinâmica Costeira \\
\hline Praia de Juçatuba & $\begin{array}{c}\text { Geomorfologia } \\
\text { Geologia }\end{array}$ & $\begin{array}{l}\text { - Dinâmica Costeira } \\
\text { - Terraço de abrasão } \\
\text { - Intemperismo }\end{array}$ \\
\hline Praia da Moça & $\begin{array}{c}\text { Geomorfologia } \\
\text { Geologia }\end{array}$ & $\begin{array}{l}\text { - Dinâmica costeira } \\
\text { - Camadas litológicas } \\
\text { - Terraço de abrasão } \\
\text { - Intemperismo } \\
\text { - Erosão }\end{array}$ \\
\hline
\end{tabular}




\begin{tabular}{|c|c|c|}
\hline $\begin{array}{l}\text { Geossítios/sítios da } \\
\text { geodiversidade } \\
\end{array}$ & $\begin{array}{c}\text { Aspecto relevante da } \\
\text { geodiversidade }\end{array}$ & Feições/Processos \\
\hline Praia de Satuba & $\begin{array}{c}\text { Geomorfologia } \\
\text { Geologia }\end{array}$ & $\begin{array}{c}\text { - Dinâmica Costeira } \\
\text { - Terraço de abrasão } \\
\text { - Falésias } \\
\text { - Intemperismo } \\
\text { - Camadas litológicas }\end{array}$ \\
\hline Morro do Pelado & $\begin{array}{l}\text { Geomorfologia } \\
\text { Geologia } \\
\text { Neotectonismo }\end{array}$ & $\begin{array}{l}\text { - Dinâmica costeira } \\
\text { - Intemperismo } \\
\text { - Neotectonismo }\end{array}$ \\
\hline Praia de Catatiua & $\begin{array}{c}\text { Geomorfologia } \\
\text { Geologia }\end{array}$ & $\begin{array}{c}\text { - Dinâmica costeira } \\
\text { - Terraço de abrasão } \\
\text { - Falésias } \\
\text { - Intemperismo }\end{array}$ \\
\hline $\begin{array}{c}\text { Praia de } \\
\text { Guarapiranguinha }\end{array}$ & $\begin{array}{c}\text { Geomorfologia } \\
\text { Geologia }\end{array}$ & $\begin{array}{l}\text { - Dinâmica Costeira } \\
\text { - Falésias } \\
\text { - Terraço de abrasão } \\
\text { - Intemperismo }\end{array}$ \\
\hline
\end{tabular}

Fonte: Adaptado pelos autores de Rabelo (2018).

As informações sumarizadas neste trabalho de inventariação foram importantes para a geração de dados mais específicos sobre aspectos geológicos e geomorfológicos observados na planície costeira do setor sudeste da Ilha do Maranhão. As etapas de campo do processo de inventário dos oito geossítios /sítios da geodiversidade foram essenciais para identificação dos principaas formas de usos humanos dos recursos abióticos que ocorrem na área, como a extração de areia e de água doce na base de falésias, e para identificar possíveis usos futuros, como, por exemplo o uso turístico dos locais que vem crescendo no setor.

Considerando os processos intempéricos e erosivos com usos humanos que acontecem na área e o acúmulo de resíduos sólidos que foi identificado na maior parte da planície costeira, é possível perceber que todos os locais inventariados encontram-se em situação de vulnerabilidade ambiental. Essas informações contidas no inventário ressaltam as limitações de cada geossítio/sítio da geodiversidade e são essenciais serem consideradas em futuras pesquisas ou ações de gestão voltadas o uso da geodiversidade deste setor.

\section{CONCLUSÕES}


A partir da síntese das informações relevantes dos geossítios/sítios da geodiversidade é possível observamos as potencialidades do ponto vista científico, didático e turístico dos pontos inventariados. Em todos os locais é possível observamos pelo menos três fatores que representam dinâmica de feições e processos na área, o que justifica a relevância destes locais sob ótica científica, principalmente considerarmos que nesta área podem ser observados características peculiares que se distinguem dos demais ambientes costeiros da Ilha do Maranhão, como a presença de morros testemunhos, camadas litológicas perpendiculares a linha de costa e extensos terraços de abrasão.

A partir do inventário feito na área percebeu-se características geológicas e, principalmente, geomorfológicas importantes que devem ser consideradas em futuros pesquisas neste setor que venham a considerar seus aspectos abióticos ou ainda quantificar o nível de relevância de cada local inventariado na área. É importante enfatizar que durante a pesquisa foi possível observar outros valores da geodiversidade na área principalmente atrelados a potenciais didático e turístico. As informações obtidas sobre a dinâmica costeira do setor sudeste da Ilha do Maranhão indicam potencialidades e limitações naturais ou causadas pela interferência antrópica na área que podem servir de base para trabalhos de planejamento e gestão ambiental que se proponham a pensar em ações e estratégias de gestão costeira na área, visto que o setor é uma atual área de expansão urbana na Ilha do Maranhão.

\section{REFERÊNCIAS}

BANDEIRA, I.C.N. Geodiversidade do Esta do do Maranhão. Programa Geologia do Brasil: levantamento da Geodiversidade CPRM. Teresina:, 2013. 299 pg.

BRILHA, J. Patrimônio Geológico e Geoconservação: a conservação da natureza na sua vertente geológica. Braga, Palimage. 2005. 183 pg.

BRILHA, J. B.R. Inventory and quantitative assessment of geosites and geodiversity sites: a review. Geoheritage, Review Articles. Online. 2015.First: 1-16.

CAÑADAS, E. S. e Flaño, P.R. Geodiverdidad: concepto, evaluación e aplicácion territorial el caso de Tiermes Caracena (Soria). Boletín de la Asociación de Geógrafos Españoles, ISSN 0212-9426, No. 45, 2007. 79-98 pg.

FEITOSA. A.C. Relevo do Estado do Maranhão: uma nova proposta de classificação topomorfológica. VI Simpósio Nacional de Geomorfologia. Goiânia. Setembro/2006. 10 pg. Disponível em: http://www.labogef.iesa.ufg.br/links/sinageo/articles/476.pdf.. 
KLEIN, E.L. et al. Geochronology, isotopes and reconnaissance geochemistry of volcanic and metavolcanic rocks of the São Luís Craton, Brazil. Precabriam Research. V. 165, n 3/4.17 pg. 2008. Disponível em: http://rigeo.cprm.gov.br/xmlui/bitstream/handle/doc/566/art_klein09_jsaes.pdf?sequence=1\&i sAllowed $=\mathrm{y}$.

LOPES, L. S. de; ARAÚJO, J. L. L. de.,e NASCIMENTO, M. A. L. do. Valores de Uso Turístico dos Geossítios de Sete Cidades (PI). Anuário do Instituto de Geociencias. Ed 35. pg. 209-221. 2012.

PEREIRA, R. G. F. de A. Geoconservação e desenvolvimento sustentável na Chapada Diamantina (Bahia - Brasil). Tese de Doutorado em Ciências com especialidade em Geologia. Universidade de Minho. 2010. 317 pg. Disponível em: http://repositorium.sdum.uminho.pt/handle/1822/10879.

PEREIRA, L.S.; CUNHA, L. S. da.; e NASCIMENTO, M. A. L. do. Emergence of Geotourism Activity at João Pessoa Municipality and South Coast of Paraíba (NE Brazil). Sustainable Geosciense and Geoturism. SCIpress. Volume 1. Pg1-10. 2018.

RABELO, O. T. Geodiversidade em ambientes costeiros: discussões e aplicações no setor costeiro da Ilha do Maranhão - Brasil, Ma. Dissertação (Mestrado). Programa de PósGraduação em Geografia da Universidade Federal do Rio Grande do Norte. 2018.153p

RODRIGUES, E. I. Estrutura da comunidade fitoplanctônica como alternativa para avaliação da sustentabilidade biológica de áreas com potencialidade aqüícola estabelecida pelo zoneamento costeiro do Estado do Maranhão. Dissertação (Mestrado). Programa de Pós-graduação em Sustentabilidade de Ecossistemas, Universidade Federal do Maranhão (UFMA). 2006. 146p.

SILVA, J. de P. Avaliação da Diversidade de padrões de canais fluviais e da geodiversidade na amazônia - aplicação e discussão na bacia hidrográfica do Rio Xingu. Tese apresentada ao Departamento de Geociências da USP. São Paulo. 2012. 298 pg. Disponível: http://www.teses.usp.br/teses/disponiveis/8/8135/tde-22022013-104907/en.php.

SILVEIRA, C. da; BASTOS, F. de H. e MEIRA, S. A. Geoconservação no Ceará: Um Olhar Sobre as Unidades de Conservação Estaduais. Revista do Departamento de Geografia da USP. Vol. 35, 58-70 pg. 2018.

SILVA, M. L. Serviços ecossistêmicos e índices de geodiversidade como suporte da geoconservação no geoparque Seridó. Dissertação de mestrado apresentada ao Programa de Pós-graduação em Geociências - Patrimônio Geopaleontológico, Museu Nacional, Universidade Federal do Rio de Janeiro. Rio de Janeiro. 168 pg. 2018.

SILVA, M. L.; NASCIMENTO, M. A. L. do e MANSUR, K. L. Quantitative Assessments of Geodiversity in the Area of the Seridó Geopark Project, Northeast Brazil: Grid and Centroid Analysis. Geoheritage. 1177-1186 pg. 2019. 